\title{
Staphylococcal food poisoning from cream-filled cake in a metropolitan area of South-Eastern Brazil*
}

\author{
Maria Lúcia Pereira**, Luiz Simeão do Carmo**, Elisângela José dos Santos**, Merlin S. Bergdoll*** \\ PEREIRA, M. L. et al. Staphylococcal food poisoning from cream-filled cake in a metropolitan area \\ of South-Eastern Brazil. Rev. Saúde Pública, 28: 406-9, 1994. Twelve people became ill with \\ vomiting and diarrhoea approximately four hours after eating cake with a cream filling at a birthday \\ party and on the day following. The cake had been prepared by a food handler who had long \\ experience in preparing foods for such functions. Staphylococcus aureus that produced enterotoxin \\ A was isolated from the nose, the fingernails, and a healed infection on the neck of the food handler, \\ and from the cake. Enterotoxin A was detected in the remaining portion of the cake. The cake, while \\ still warm, had been refrigerated for one hour after it was prepared before it was removed for the \\ party; it was refrigerated after the party. The cake was large $(6 \mathrm{~kg})$ and hence it was not adequately \\ cooled in the hour during wich it was refrigerated before the party. The conclusion is that the cake \\ was accidentally contaminated by the food handler and inadequately cooled before it was eaten.
}

Keywords: Staphylococcal food poisoning, epidemiology. Food handling. Enterotoxins, analysis.

\section{Introduction}

Staphylococcal food poisoning is much more common in Brazil than is recognized. Most cases are never reported or investigated. One paper has been published recently on several outbreaks occurring in S. Paulo (Cerqueira Campos et al. ${ }^{3}$, 1993). Several outbreaks have been investigated in the city of Curitiba, Paraná State (Bergdoll et al. ${ }^{2}$, 1992), but the major emphasis on investigating outbeaks has been in the city of Belo Horizonte, Minas Gerais State (Carmo and Bergdoll ${ }^{4}$, 1990; Carmo et al .5, 1995). This has resulted in the establishment of a Staphylococci laboratory at the "Fundação Ezequiel Dias". This laboratory is primarily a research laboratory and with the help of graduate students has investigated problems related to the outbreaks in Minas Gerais State. Research was done on the involvement of cream-filled cakes (Anunciação et al."***, 1994) and a white cheese (Anunciação et al ${ }^{1}, 1994$ ) characteristic of food poisoning in Minas Gerais State. These two foods have been the cause of

* Supported in part by the "Fundação de Amparo à Pesquisa de Minas Gerais (FAPEMIG) - Project no 374/90.

** Fundação Ezequiel Dias. Laboratório de Staphylococci. Belo Horizonte, MG - Brasil

*** Food Research Institute. University of Wisconsin. Madison - USA

**** Refers to the research "Production of staphylococcal enteroxin a in cream-filled cake. Unpublished.

Reprints: L.S. do Carmo - Rua Conde Pereira Cameiro, 80Gameleira - 30510-010 - Belo Horizonte, MG - Brasil almost all of the outbreaks reported in Minas Gerais State (Carmo and Bergdoll $\left.{ }^{4}, 1990\right)$. One problem with the outbreaks is that they are seldom investigated as to the source of the causative organism. Most staphylococcal food poisoning outbreaks are a result of contamination by humans as they are common carriers of enterotoxigenic staphylococcis.

The present work covers the investigation of a typical staphylococcal food poisoning outbreak in Minas Gerais State resulting from the consumption of a cream-filled cake at a birthday party and on the following day.

\section{Description of outbreak}

Three children and four adults became ill with vomiting and diarrhoea four and one-half hours after eating cream-filled cake at a birthday party. The following day four adults and one child became ill with vomiting and diarrhoea after eating some of the left-over cake which had been kept in the refrigerator. The child was hospitalized. All who became ill had eaten cake. Six adults who ate cake at the party did not become ill, whereas all of those who ate cake the following day became ill. Recovery ocurred within $24 \mathrm{~h}$. The symptoms are typical of those observed in staphylococcal food poisoning .

The individual who made the cake $(6 \mathrm{~kg})$ placed the cream filling in the cake one hour before the party and put the cake in the refrigerator while it was still warm. The cream filling was prepared while the cake was being baked. The 
cake was removed from the refrigerator for the party and was consumed two hours after the party began. It is doubt ful that the cake was cooled sufficiently to stop the growth of the staphylococci, particularly in the inside of the cake, because of its an extra large size. At the time of the preparation of the cake, the individual preparing the cake had an infection on her neck, otherwise she was in good health. She had been preparing food for other occasions for several years without any problems.

\section{Material and Method}

\section{Bacterial cultures}

Swabs were taken from the neck, nares, throat, and fingernails of the food handler four days after the party.

\section{Isolation of staphylococci}

Each swab was placed in a tube of tryptic soy broth containing $10 \% \mathrm{NaCl}$ and incubated for $24 \mathrm{~h}$ at $37^{\circ} \mathrm{C}$. The cultures were streaked on Baird-Parker plates and incubated for 48 hours at $37^{\circ} \mathrm{C}$. Five typical colonies (jet black to dark grey, smooth, convex, entire margins, off-white edge, and may show an opaque zone and/or a clear halo beyond the opaque zone) and three atypical colonies (gray and mucoid) were selected for further testing. Each colony was transferred to two test tubes containing $1 \mathrm{ml}$ of brain heart infusion (BHI) - broth and incubated for 24 hours at $37^{\circ} \mathrm{C}$. Tests for coagulase and thermonuclease (TNase) production anaerobic fermentation of glucose and mannitol, and production of hemolysin using sheep blood were made. Any colonies that were positive for these characteristics were considered $S$. aureus and were tested for enterotoxin production.

\section{Determination of staphylococcal count}

Twenty-five grams of the cake filling was suspended in $225 \mathrm{ml}$ of buffered peptone water; $0.1 \mathrm{ml}$ was placed on Baird-Parker agar plates. Additional plates were prepared with 10-fold dilutions if necessary (Tatini et al. ${ }^{10}, 1984$ ). The plates were incubated for $48 \mathrm{~h}$ at $37^{\circ} \mathrm{C}$.

\section{Enterotoxin production}

For enterotoxin production, inocula were prepared by combining the five isolates from each site and incubating them in BHI broth overnight at $37^{\circ} \mathrm{C}$. Membrane-over-agar plates were prepared with $25 \mathrm{ml}$ of $\mathrm{BHI}$-agar and covered with a membrane disk made from Spectra/Por membrane dialysis tubing, $6000-8000,100 \mathrm{~mm}$ flat width (Thomas Scientific, Philadelphia, PA, USA) (Robbins et al. ${ }^{9}, 1974$ ). One-half milliliter of the inoculum was spread on the membrane and the plates were incubated at $37^{\circ} \mathrm{C}$ for $24 \mathrm{~h}$. The cultures were removed from the membranes by washing with $2.5 \mathrm{ml}$ of $0.01 \mathrm{M} \mathrm{Na}_{2} \mathrm{HPO}_{4}$ in three steps using $1 \mathrm{ml}, 1 \mathrm{ml}$, and $0.5 \mathrm{ml}$ of the phosphate buffer. The cultures were centrifuged and the culture supernatant fluids used for enterotoxin testing.

\section{Enterotoxin testing}

The optimum-sensitivity-plate (OSP) method was used (Robbins et al. ${ }^{9}, 1974$ ). In this method, $3 \mathrm{ml}$ of agar $(1.2 \%)$ is placed in $50 \mathrm{~mm}$ plastic petri plates with tight lids: wells are cut according to the original specifications. Specific antisera is placed in the center well, enterotoxin $(4 \mu \mathrm{g} /$ $\mathrm{ml}$ ) is placed in the two smaller wells, and culture supernatant fluids are placed in the four larger outer wells. Different plates are required for each enterotoxin (SEA, SEB, SEC, SED). The plates are placed in a humidified container and incubated overnight at $37^{\circ} \mathrm{C}$. Positive reactions are determined from precipitin lines formed by the culture supernatant fluids that joined with the control lines.

\section{Enterotoxin detection in the cake}

Fifty grams of the cake containing the cream filling was homogenized in a Waring blender

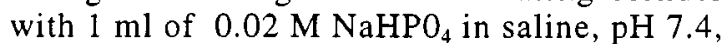
per gram of food (Freed et al. ${ }^{7}, 1982$ ). The $\mathrm{pH}$ of the supernatant fluid was readjusted to $\mathrm{pH} 7.4$. The extract was tested for the presence of enterotoxin by use of the ELISA ball kit* (Fey and Pfister ${ }^{6}, 1983$ ). This method is sensitive to $0.5 \mathrm{ng} / \mathrm{ml}$ and is the most reliable of the sensitive methods available for checking foods for enterotoxin (Wieneke ${ }^{11.12}, 1987,1991$ ). One antibody-coated ball for each enterotoxin (A-D) plus one ball coated with normal rabbit sera were placed in $20 \mathrm{ml}$ of food extract and shaken gently overnight. Each ball was removed from the extract and washed with the wash solution and each placed in a color coded tube for treatment with

* Obtained from Dr. Bomelli AG, Stationstrasse 12, CH-3097 Libbefeld-Bern, Switzerland 
the conjugate. After $6 \mathrm{~h}$ the conjugate was removed and the balls washed with the wash solution. One $\mathrm{ml}$ of the substrate was added and the color allowed to develop for $45 \mathrm{~min}$. If any color developed, the extract was judged to contain the enterotoxins for which a color developed.

\section{Results}

Each of the five isolates from the food handler's throat, nasal passages, fingernails, and infection and from the cake was coagulase and TNase positive, fermented glucose and mannitol anaerobically, and were hemolytic. It was concluded that the isolates were Staphylococcus aureus because it is the only species carried by humans that is both coagulase- and TNasepositive and ferments mannitol anaerobically.

The staphylococcal count was $1.2 \times 10^{8}$ cfu/g of cake.

Examination by the OSP method showed isolates from all of the culture sites, except the isolates from the throat, and the ones from the cake produced enterotoxin A (SEA) (Table).

Enterotoxin A (SEA) was detected in the cake implicated in the food poisoning outbreak (Table).

\section{Discussion}

This outbreak was a typical staphylococcal food poisoning outbreak resulting from the eating of a food served at a function involving a number of people. Although the twelve who fell ill was not a large number, all had eaten the same food, a cream-filled cake. Six people who ate the cake at the party did not become ill, indicating that those eating the cake on the day it had been made did not receive as much toxin as those who ate the cake on the following day. Although the cake had been refrigerated after the party, the staphylococci would continue. To grow in the cake and produce enterotoxin until adequate cooling, took place. The cream filling was placed in the cake while the cake was still warm and the

Table. Biochemical characteristics and enterotoxin production of isolates from staphylococcal cake poisoning.

\begin{tabular}{lcccccc}
\hline Isolates Coag. & TNase & Mann.(an) & Glu.(an) & Hemol. & Enterotoxin \\
\hline Nose" & + & + & + & + & + & SEA \\
Throata $^{a}$ & + & + & + & + & Neg \\
Neck $^{a}+$ & + & + & + & + & SEA \\
Fingemails $^{a}$ & + & + & + & + & SEA \\
\hline Cake $^{b}+$ & + & + & + & + & SEA \\
\hline
\end{tabular}

a - From food handler who prepared the cake

b. $1,2 \times 10^{8} \mathrm{cfu} / \mathrm{g}$ of cake cake was refrigerated for one hour before the party. It is unlikely that the cake cooled adequately, especially because of its size, to prevent the staphylococci from continuing to grow until it was consumed. However, the amount of enterotoxin in the cake at the time of the party was probably small as it required over $4 \mathrm{~h}$ after the cake was eaten before the symptoms developed, considering that symptoms may develop between one and 6 hours after consumption of food containing enterotoxin. Although refrigeration is the recommended method for preventing staphylococcal food poisoning, if food is exposed to room or warmer temperatures for 2 to 3 hours without refrigeration, enough growth and enterotoxin production could take place to result in food poisoning. Another concern it the size of the food item refrigerated. In this case the cake was extra large which made it doubt ful that the interior of the cake could have cooled sufficiently to prevent the staphylococci to continue growing. If possible food should be refrigerated in small quantities.

The majority of staphylococcal food poisoning outbreaks result from the contamination of the food during its preparation by the food handler. Humans are common carries of enterotoxigenic staphylococci in the nose and throat, or on the skin. In addittion many infections can be caused by staphylococci, which is a more dangerous situation because they are present in large numbers and can easily be transferred to the food being handled. Many staphylococcal food poisoning outbreaks have resulted from foods prepared by food handlers with infections. It is recommended that foods being prepared for groups should not be prepared by a food handler with any type of infection. The wearing of surgeon's gloves during the preparation of the food would add insurance against contamination of the food, providing the food handler avoided touching any other part of the body with the hands during the preparation of the food.

PEREIRA, M.L. et al. Intoxicação estafilocócica causada por bolo recheado em área metropolitana do sudeste do Brasil. Rev. Saúde Pública, 28: 406-9 ,1994. Doze pessoas foram acometidas de vômito e diarréia aproximadamente 4 horas após haverem ingerido bolo recheado, servido em uma festa de aniversário, e no dia seguinte à festa. Staphylococcus aureus produtor de enterotoxina A foi isolado no bolo, fossa nasal, leito subungueal e, essencialmente, em uma ferida em fase de cicatrização, localizada na nuca da manipuladora, que dispunha de longa experiência na área de produção de alimentos. $O$ bolo, de cerca de $6 \mathrm{~kg}$, quando ainda quente, foi levado ao refrigerador, por uma hora antes de ser servido não tendo 
portanto, sido convenientemente resfriado. Esses dados permitiram concluir que o referido alimento foi, acidentalmente, contaminado pela manipuladora $\mathrm{e}$ inadequadamente resfriado antes de ser ingerido.

Descritores: Intoxicação alimentar estafilocócica, epidemiologia. Manipulação de alimentos. Enterotoxinas, análise.

\section{References}

1. ANUNCIACÃO, L.L.C.; LINARDI, W.R.; CARMO, L.S do; BERGDOLL, M. S. Production of staphylococcal enterotoxin $A$ in white cheese. Rev. Microbiol., 25: 6871,1994

2. BERGDOLL, M.S.; CARMO, L.S. do; MOSCALEWSKI, W.S.; BRANCO FILHO, M.O. Staphylococcal food poisoning in Brazil: In: World Congress Foodborne Infections and Intoxications, 3rd., Berlin, 1992. Proceedings. v. 1, p. 320-23.

3. CERQUEIRA-CAMPOS, M.L.; FURLANETTO, S.M.P.; IARIA, S.T.; BERGDOLL, M.S. Staphylococcal food poisoning outbreaks in São Paulo (Brazil). Rev. Microbiol., 24:261-4, 1993.

4. CARMO, L.S. do \& BERGDOLL, M.S. Staphylococcal food poisoning in Belo Horizonte (Brazil). Rev. Microbiol., 21:320-3, 1990.

5. CARMO, L.S. do; DIAS, R.S.; ANUNCIACÃO, L.L.C.; BERGDOLL, M.S. Staphylococcal food poisoning in Minas Gerais State (Brazil). Arq. Bras. Med. Vet., jan., 1995. [in press].
6. FEY, H. \& PFISTER, H. A diagnostic kit for the detection of staphylococcal enterotoxins (SET) A, B, C, and D (SEA, SEB, SEC, SED). In: Avrameas, S., ed. Immunoenzymatic techniques. Amsterdam, Elsevier. 1983. p.345-8.

7. FREED, R.C.; EVENSON, M.L.; REISER, R.F.; BERGDOLL, M.S. Enzyme-linked immunosorbent assay for detection of staphylococcal enterotoxins in food. Appl. Environ. Microbiol., 44:1349-55, 1982.

8. PEREIRA, M.L.; CARMO, L.S. do; LARA, M.A. de; DIAS, R.S.; BERGDOLL, M.S. Enterotoxigenic staphylococci from food handlers working in an industrial kitchen in Belo Horizonte(Brazil). Rev. Microbiol., 25:161-5, 1994.

9. ROBBINS, R.; GOULD, S.; BERGDOLL, M. Detecting the enterotoxigenicity of Staphylococcus aureus strains. Appl. Microbiol., 28:946-50, 1974.

10. TATINI, S.R.; HOOVER, D.G.;LACHICA, R.V.F. Methods for the isolation and enumeration of Staphylococcus aureus. In: Speck, M.L., ed. Compendium of methods for the microbiological examination of foods. Washington, American Public Health Association, 1984. p. 411-27.

11. WIENEKE, A.A. Comparison of four methods for the detection of staphylococcal enterotoxin in food from outbreaks of food poisoning. Int. J. Food Microbiol., 4:135-43, 1987.

12. WIENEKE, A.A. Comparison of our kits for the detection of staphylococcal enterotoxin in foods from outbreaks of food poisoning.Int.J.FoodMicrobiol., 14:305-12, 1991.

Submitted in 4.25.1994 Approved in 10.24.1994 